\title{
PENENTUAN LOKASI USAHA YANG STRATEGIS DAN FAST RESPONS PADA UMKM DESA SIPAYUNG KECAMATAN SUKAJAYA KABUPATEN BOGOR
}

\author{
Ari Soeti Yani \\ Fakultas Ekonomi Dan Bisnis Universitas 17 Agustus 1945 Jakarta \\ Email: arisoetiyani@gmail.com
}

\begin{abstract}
ABSTRAK
Program Pengabdian Kepada Masyarakat ini bertujuan untuk menentukan lokasi usaha yang strategis dan fast respons pada UMKM Desa Sipayung agar tepat sasaran. Adapun penentuan lokasi tersebut memiliki faktor-faktor yang perlu dipertimbangkan antara lain dilihat dari lingkungan masyarakat, kedekatan dengan pasar, adanya tenaga kerja yang murah, kedekatan dengan bahan mentah, tersedianya fasilitas dan biaya transportasi serta tersedianya lahan untuk perluasan usahanya. Sedangkan kegunaan khususnya bagi masyarakat Desa Sipayung lebih memahami bagaimana caranya menentukan lokasi usaha yang strategis dan menganalisa biaya lokasi yang tepat agar diperoleh perbandingan ekonomi dan lokasi yang sesuai dengan mengidentifikasi biaya tetap dan variabelnya sehingga akan dapat ditentukan mana yang termasuk biaya yang lebih efisien dan efektif dalam penentuan lokasi usaha yang strategis untuk UMKM tersebut. Sedangkan yang dimaksud dengan fast respons disini agar masyarakat Desa Sipayung cepat tanggap dalam menghadapi permintaan pasar dan persaingan usaha. Untuk itu diperlukan tips bagi fast respons yaitu perlu adanya komunikasi yang baik, perlu informasi yang tepat, dan rasa nyaman serta berani untuk menghadapi masalah yang ada.
\end{abstract}

Kata Kunci: Penentuan lokasi usaha yang strategis, Fast Respons, Komunikasi yang baik dan perluasan usaha . 


\section{ABSTRACT}

This Community Service Program aims to determine the strategic business location and fast response at Sipayung Village SMEs so that it is right on target. The location determination has factors that need to be considered, among others, seen from the community environment, proximity to the market, the availability of cheap labor, proximity to raw materials, availability of facilities and transportation costs and the availability of land for business expansion. Meanwhile, the usefulness, especially for the Sipayung Village community, better understand how to determine a strategic business location and analyze the exact location costs to obtain an appropriate economic and location comparison by identifying fixed costs and variables so that it can be determined which one is more cost-efficient and effective in determining the strategic business location for the MSME. Whereas what is meant by fast response here is that the people of Sipayung Village can be responsive in facing market demand and business competition. For this reason, tips for fast responses are needed, namely the need for good communication, appropriate information, and a sense of comfort and courage to deal with existing problems.

Keywords: Strategic business location determination, Fast Response, Good communication, and business expansion

\section{PENDAHULUAN}

Desa Sipayung merupakan salah satu desa di Kecamatan Sukajaya Kabupaten Bogor Jawa Barat. Desa tersebut berada di kawasan Taman Nasional Gunung Halimun Salak ini menyimpan sejuta pesona alam yang sangat layak menjadi destinasi wisata. Desa Sipayung termasuk Desa yang cukup maju dibandingkan dengan desa-desa lainnya di Kecamatan Sukajaya, ini terlihat dari jalananya yang menuju di kampung-kampung lainnya sudah cukup bagus, dan masyarakat rata=rata mempunyai usaha sampingan selain sebagai petani dan buruh tani. Desa Sipayung banyak dikunjungi pengunjung karena tempatnya sangat strategis dan mudah sekali dijangkau. Manfaat potensi lokal yaitu keindahan alam, pertanian dan budayanya. Masyarakat desa Sipayung sangat terbuka dan bergotong royong dalam menjalankan semua kegiatannya, contohnya dalam membangun setiap jalan setapak untuk menghubungksan dengan desa yang lainnya, selain itu setiap kegiatan yang dianjurkan oleh Kepala Desa setempat masyarakatnya dengan antusias mengerjakannya.

Tujuan yang diharapkan dengan adaaya kegiatan ini khusunya masyarakat Desa Sipayung adalah dapat menentukan lokasi usaha yang sangat strategis dan fast respons pada UMKM tentunya dengan kiat-kiat sebagai berikut adanya komunikasi yang baik dengan lingkungan masyarakat sekitarnya dengan keseriusan, karena keseriusan 
merupakan kunci kesuksesan usaha yang akan dijalankan, selain itu perlunya informasi yang tepat, sehingga akan memberikan respon yang cepat kepada pembeli, tentunya perlu adanya kenyamanan saat pembeli datang dan berani untuk menghadapi setiap masalah yang muncul.

Desa Sipayung sebenarnya termasuk desa yang sudah cukup maju untuk di kembangkan sebagai desa wisata. Di sepanjang jalan sudah sangat rapi baik itu jalanan setapak sebagai penghubung dengan desa lainnya sudah teratur dengan baik, artinya semua jalanan sudah di aspal sehingga aksesnya mudah terjangkau.

Permasalahan pada masyarakat setempat masih menganut pada kesepuhan Halimun. Hal ini telah menjadi sumber perilaku antara masyarakat Desa Sipayung terhadap adat sampai saat ini masih mempengaruhi pola perilaku sehari - hari gaya arsitektur pada pembangunan rumah dan cara bertani serta cara berfikir masyarakat dalam kesehariannya. Artinya masyarakat belum mengetahui bahwa desa tersebut cukup potensial untuk dijadikan tempat wisata. Untuk itu masyarakat lebih banyak mengikuti pelatihan pelatihan yang di selenggarakan oleh pemerintah untuk memajukan desanya, seperti bagaimana cara untuk menentukan lokasi usahanya, mengembangkan usaha serta cara memasarkan hasil usahanya. Di sini Kepala Desa Sipayung tak henti - hentinya mengadakan pelatihan baik di adakan di Balai desa maupun mengutus beberapa warganya untuk mengikuti pelatihan diselenggarakan kerja sama baik swasta dan yang diselenggarakan oleh kabupaten Bogor.

\section{METODE PELAKSANAAN}

Pelaksanaan program pengabdian kepada masyarakat ini terbagi dalan dua kegiatan, yaitu penyuluhan dan pelatihan. Adapun uraian dua kegiatan tersebut sebagai berikut:

a. Program penyuluhan pemanfaatan lahan yang akan dijadikan perluasan usahanya untuk meningkatkan pendapatan usaha masyarakat Desa Sipayung dilaksanakan dalam dua kali pertemuan. Setiap pertemuan dilaksanakan selama satu jam efektif

b. Program pelatihan pemanfaatan limbah rumah tangga untuk peningkatan pendapatan bagaimana cara menganalisa biaya lokasi usaha, bagaimana memasarkan hasil usahanya serta bagaimana untuk mengembangkan hasil usahanya.

Partisipasi mitra di dalam kegiatan penyuluhan dan pelatihan penentuan usaha yang strategis dan fast respons untuk meningkatkan pendapatan usahanya yaitu dengan 
menyediakan fasilitas tempat untuk pelaksanaan kegiatan tersebut yaitu di Balai desa Sipayung dan Sekolah PAUD sebagai tempat pertemuan. Istrumen yang digunakan pada program pengabdian kepada masyarakat ini meliputi; (1) sound system, (2) kursi, (3) LCD Proyektor, (4) kamera dan lain-lain.

Lokasi kegiatan adalah Desa Sipayung Kecamatan Sukajaya Kabupaten Bogor Jawa Barat. Waktu pelaksanaan sejak mulai persiapan dari bulan Mei sampai dengan pelaksanaan mulai tanggal 13- 14 Agustus 2019.

\section{HASIL DAN PEMBAHASAN}

Pengabdian masyarakat dilaksanakan sesuai rencana yang telah dibuat sebelumnya. Pesrta yang diharapkan hadir telah menempati ruangan Balai desa dan Sekolah PAUD sesuai jadwal, karena sosialisasi dari aparat desa kepada warga setempat telah disampaikan sebelumnya secara keseluruhan dan pelaksanaanya berjalan lancar.

Peserta sangat antusias mengikuti penyuluhan ceramah serta pelatihan yang diberikan, khususnya mengenai bagaimana menentukan lokasi usaha yang strategis dan perlunya fast respons ( cepat tanggap ) dari pengusahanya. Hal ini tentunya dapat menjaga kelangsungan hidup UMKM di masa yang akan datang. Materi yang disiapkan di disain sedimikian rupa agar dapat mudah dipahami oleh warga biasa dimana pendidikannya rata-rata masih rendah. Materi disampaikan dengan bahasa yang sederhana dan pelatihan secara langsung.Pada bagian tertentu diterjemahkan ke dalam bahasa daerah Sunda agar lebih dapat dipahami oleh warga setempat peserta pelatihan.

Pelaksanaan dilaksanakan dalam semester genap tahun ajaran 2018/2019 pada hari Selasa dan Rabu tanggal 13 - 14 Agustus 2019. Sesi pelaksanann dibagi berdasarkan materi yang akan disampaikan.

Dengan adanya penyuluhan dan pelatihan yang diadakan oleh dosen FEB Universitas 17 Agustus 1945 Jakarta diharapkan kedepannya dapat memanfaatkan lahan untuk perluasan usahanya sehingga kelangsungan hidup UMKM Desa Sipayung yang lebih langgeng.

Peserta pelatihan dan penyuluhan sudah memahami perlunya menentukan letak usaha yang strategis dan perlunya fast respons/ cepat tanggap dari seorang pengusaha dalam menghadapi persaingan bisnis dengan contoh-contoh yang disesuaikan dengan kondisi 
yang dialami oleh peserta, serta mereka dapat memahami dan mempraktekanya dalam simulasi.

Adapun tentang penentuan suatu usaha, dimana usaha akan didirikan dan dibagian mana daerah itu akan didirikan usaha, pemilihan letak usaha pada umumnya dipengaruhi oleh beberapa faktor (Hery Prasetya-Fitri Lukiastuti, 2008).

Setelah lokasi ditentukan maka harus menentukan dibagian mana usaha tersebut akan didirikan. Berbagai faktor yang perlu diperhatikan untuk pemilihan tempat, antara lain:

a. Tanah harus kering dan kuat untuk menyangga bangunan

b. Mempunyai keamanan dan perlindungan kebakaran yang baik

c. Dekat dengan transportasi masyarakat

d. Cukuo tersedia area untuk usaha, ekspansi dan parkir kendaraan karyawan

(Jay Heizer-Barry Render, 2015).

Perlu ada pelatihan berkelanjutan dan penijauan ulang kelokasi, guna memastikan bahwa warga dapat memanfaatkan lahan untuk perluasan usahanya sehingga kelangsungan hidup dan pengembangan usahanya berjalan lancar
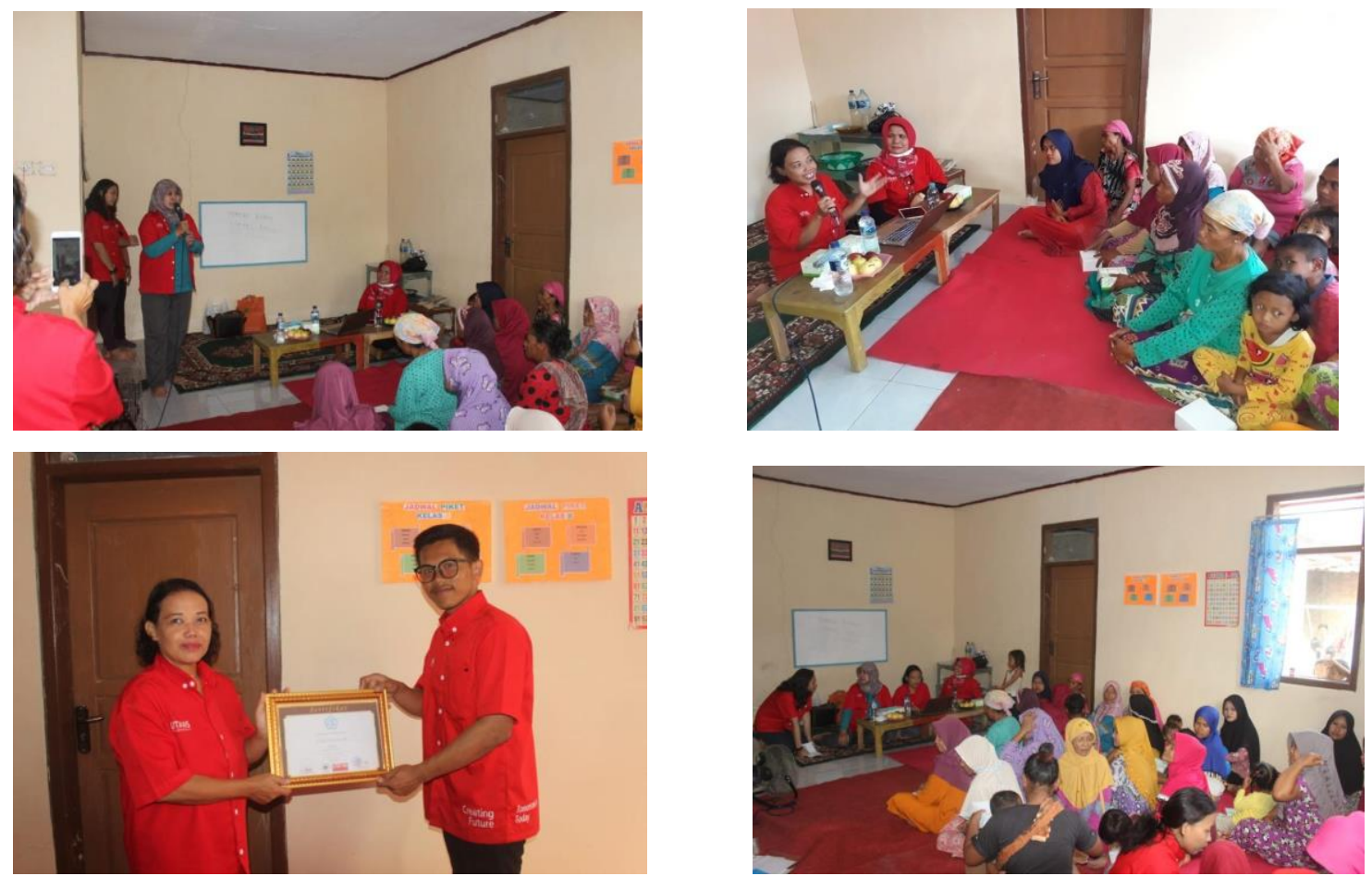

Gambar 1. Dokumentasi kegiatan abdimas dosen feb uta '45 jakarta 


\section{KESIMPULAN}

Berdasarkan pelaksanaan program pengabdian kepada masyarakat dapat disimpulkan bahwa secara ekonomis, hadirnya mahasiswa KKN dilokasi telah menambah geliat ekonomi pada penduduk setempat. Kontak mahasiswa dengan penduduk juga memberikan kesempatan kepada kedua belah pihak untuk saling memahami dan memperluas wawasannya masing-masing. Hadirnya mahasiswa dengan program-program pelatihan dan penyuluhan membawa dampat yuang positif bagi mahasiswa itu sendiri dan bagi warga dilokasi khususnya dalam menentukan lokasi usaha yng strategis dan perlunya fast respons dari penguhasanya.

\section{REKOMENDASI}

1. Kepala Desa Sipayung Kecamatan Sukajaya Kabupaten Bogor Jawa Barat yang telah member waktu dan tempat kepada kami untuk melaksanakan penyuluhan di Desa Sipayung

2. Para mahasiswa yang sudah mengundang saya sebagai pembecara dalam penyuluhan tentang : Penentuan Lokasi Usaha Yang Strategis dan Fast Respon pada UMKM di Desa Sipayung Kemacamatan Sukajaya.

\section{UCAPAN TERIMAKASIH}

Ucapan terimakasih ditujukan kepada Universitas 17 Agustus 1945 Jakarta khususnya Lembaga Pengabdian Kepada Masyarakat yang telah mendanai kegiatan penyuluhan ini di desa Sipayung,selain itu teman - teman Dosen FEB UTA 45 Jakarta yang telah berpartisipasi dalam penyelenggaraan acara kami.

\section{DAFTAR PUSTAKA}

Prasetya, Hery dan Lukiastuti, Fitri, 2008, Manajemen Operasi, MedPress

Render dan Jay, Barry dan Heizer, 2015, Operation Management, Edisi 11, Pearson Education. 